\title{
Determining contemporary and historical sediment sources in a large drainage basin impacted by cumulative effects: the regulated Nechako River, British Columbia, Canada
}

\author{
David Gateuille ${ }^{1,2} \cdot$ Philip N. Owens ${ }^{1,3} \cdot$ Ellen L. Petticrew ${ }^{1,4} \cdot$ Barry P. Booth $^{1} \cdot$ Todd D. French $^{3,4} \cdot$ Stephen J. Déry ${ }^{1,3}$
}

Received: 31 August 2018 / Accepted: 3 March 2019 / Published online: 27 March 2019

(C) The Author(s) 2019

\begin{abstract}
Purpose Sediment dynamics in most large river basins are influenced by a variety of different natural and anthropogenic pressures, and disentangling these cumulative effects remains a challenge. This study determined the contemporary and historical sources of fine-grained $(<63-\mu \mathrm{m})$ sediment in a large, regulated river basin and linked changes in sources to activities in the basin. The river has seen declines in chinook salmon, sockeye salmon, and the endangered Nechako white sturgeon populations, and sediment (both fine-grained and sands) transport and deposition have been identified as potential causes of these declines. Materials and methods Samples of suspended sediment and potential source materials were collected from numerous sites distributed throughout the upper Nechako River Basin in British Columbia, Canada. A floodplain sediment core was also collected in order to reconstruct sediment sources over the last $\sim 70$ years. Discriminating fingerprint properties were used within the MixSIAR model to apportion sources among sub-basins and land-use types. Results were compared to records of precipitation and Nechako River discharge trends, and to changes in landscape development.

Results and discussion Contributions from the erosion of channel banks dominated the suspended sediment load at most sites. Changes in sediment sources during the 2015 field season reflected snowmelt and patterns of water release from the Nechako Reservoir that affected the sediment-carrying capacity of tributaries and the Nechako River main stem. Spatial variations in 2015 also reflected the distribution of land use (e.g., forested or agricultural land) as well as topography (e.g., slope steepness). Over the last $\sim 70$ years, variations in sediment sources and the characteristics of the sediment (e.g., organic matter content and particle size composition) were linked to the construction of the Kenney Dam (operational in 1954) and the impacts of deforestation by the forestry and agricultural industries. Superimposed on these have been wildfires and a major mountain pine beetle infestation leading to higher erosion rates in the affected areas.

Conclusions The sediment source fingerprinting technique, in combination with historical information on the hydrometeorology and the land use and river management in the basin, has provided valuable information with which to understand sediment dynamics in the Nechako River Basin. Such an approach can help to disentangle how large river systems respond to a combination of natural and anthropogenic pressures.
\end{abstract}

Keywords Land-use changes $\cdot$ MixSIAR $\cdot$ Nechako white sturgeon $\cdot$ Reservoir management $\cdot$ Sediment fingerprinting

\section{Responsible editor: Patrick Laceby}

Electronic supplementary material The online version of this article (https://doi.org/10.1007/s11368-019-02299-2) contains supplementary material, which is available to authorized users.

Philip N. Owens

philip.owens@unbc.ca

1 Integrated Watershed Research Group, University of Northern British Columbia, 3333 University Way, Prince George, British Columbia V2N 4Z9, Canada

2 Laboratoire LCME, Université Savoie Mont Blanc, 73000 Chambéry, France
3 Environmental Science Program and Quesnel River Research Centre, University of Northern British Columbia, 3333 University Way, Prince George, British Columbia V2N 4Z9, Canada

4 Geography Program and Quesnel River Research Centre, University of Northern British Columbia, 3333 University Way, Prince George, British Columbia V2N 4Z9, Canada 


\section{Introduction}

The Earth's "critical zone" represents a fragile layer that supports most terrestrial life, and thus is the zone in which most humans live and modify in order to sustain life, especially in terms of forest products, food (i.e., agriculture), and water supply. Hydrologically, the critical zone is composed of drainage basins which route water, chemicals, and sediment from areas of higher elevation to the global ocean. Most large river basins are impacted by cumulative pressures, such as river regulation, land-use change, urbanization, resource extraction, and climate change (Schindler and Smol 2006; Vörösmarty et al. 2010). Such pressures express themselves in several ways, some of which can be measured, such as changes in water quantity and quality, and changes in ecological functioning. In reality, disentangling these cumulative effects is complicated because of temporal and spatial variations in how these individual effects operate, the potential for synergistic interactions, and issues of disconnectivity in landscapes, and because there are time lags between the start of an effect and the (measured) response (e.g., Smith and Owens 2014a; Wohl et al. 2019). The end result is that scientists and managers are often not capable of disentangling cumulative effects in large, complex river basins.

The Nechako River Basin (NRB) is typical of many large river basins in Canada, and elsewhere, in that it has experienced considerable changes in the last few decades or so in response to cumulative effects. The most dramatic of these in terms of river flows and aquatic species was the construction of the Kenney Dam in the early 1950s and the creation of a 920$\mathrm{km}^{2}$ reservoir; the purpose being to redirect water westwards against the hydraulic gradient to power an aluminum smelter near the British Columbia coast. The Nechako is now a regulated river. Since the construction of the dam and reservoir, there has been concern from communities in the river basin over the amount and timing of river flows, including periods of low flows and also downstream flooding associated with reservoir operations (Hartman 1996; French and Chambers 1997; Albers et al. 2016). There is also concern for aquatic organisms in the river, especially the Nechako white sturgeon (Acipenser transmontanus), which started to decline dramatically in the 1960s, and is now listed as an endangered species (McAdam et al. 2005). The river also provides important spawning habitat for anadromous chinook salmon (Oncorhynchus tshawytscha) and sockeye salmon (O. nerka). There have also been land-use changes such as an expansion of agriculture and forest harvesting, and associated road networks, as well as resource extraction (e.g., mining) over this period (Hartman 1996). In addition to anthropogenic pressures, the river basin has: experienced changes in temperature and precipitation associated with global climate change (Danard and Murty 1994; Déry et al. 2012; Kang et al. 2016); recent episodes of severe wildfires; and a catastrophic outbreak of mountain pine beetle (Dendroctonus ponderosae), which started in the early 1990s and subsequently spread to large parts of North America (NRC 2018). These outbreaks have significantly diminished lodgepole pine (Pinus contorta) tree populations which, in turn, have likely contributed to soil instability and erosion.

One of the manifestations of these changes has been the amount and quality (e.g., texture, concentrations of nutrients and contaminants) of sediment transported and stored within the river channel system (e.g., Owens et al. 2019). Indeed, increased storage of sediment - both fine-grained (silt and clays; $<63 \mu \mathrm{m}$ ) and sands ( $>63 \mu \mathrm{m}$ to $2 \mathrm{~mm}$ ) - in river channel gravels has been identified as a possible reason for the decline in the Nechako white sturgeon population (McAdam et al. 2005), as well as chinook and sockeye salmon stocks (Jaremoviec and Rowland 1988) that spawn in tributary systems to the Nechako River. There has, therefore, been considerable interest in identifying where the sediment originates and what might be the cause of any change in the amount and nature of the sediment fluxes. The sediment fingerprinting technique (Walling 2013; Owens et al. 2016; Collins et al. 2017) offers the potential to address some of these issues, especially as it can be used to reconstruct changes in sediment sources and dynamics in river basins over timescales of decades to hundreds of years (e.g., Collins et al. 1997; Owens and Walling 2002; Walling et al. 2003; D'Haen et al. 2012). In this context, the objectives of this study were to: (i) identify the contemporary sources of fine-grained sediment transported in the middle to upper reaches of the Nechako River; (ii) reconstruct the main sediment sources since the construction of the Kenney Dam and Nechako Reservoir; and (iii) assess any changes in sediment sources in the context of cumulative effects.

\section{Materials and methods}

\subsection{Study area and sample collection}

The NRB is located in central British Columbia (Fig. 1). It drains $47,200 \mathrm{~km}^{2}(\sim 5 \%$ of mainland British Columbia) and it is the Fraser River's second largest tributary. It joins the Fraser River at the city of Prince George ( 74,000 people). The Fraser River Basin $\left(234,000 \mathrm{~km}^{2}\right)$ drains about $25 \%$ of British Columbia and discharges to the Pacific Ocean at Vancouver. Surficial geology in the NRB is dominated by Tertiary volcanic and volcanoclastic rocks and Quaternary glacial deposits which are underlain by Jurassic to Cretaceous sedimentary strata and Mesozoic igneous rock (Calvert and Andrews 2014). Parent soil materials in the NRB are mostly comprised of gray basal or colluviated sandy tills; surficial humus layers are typically thin $(2-4 \mathrm{~cm})$ with predominantly brunisols beneath (Cook and Dunn 2006). The 

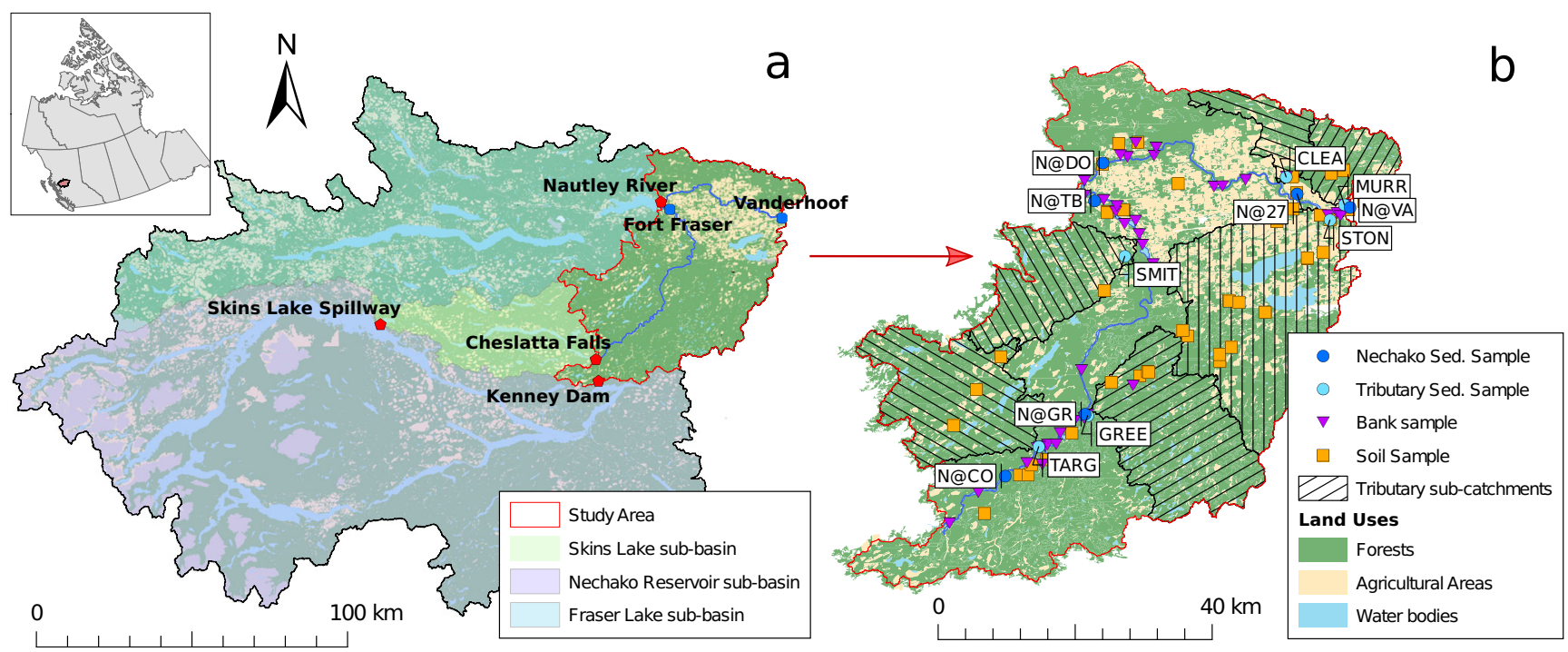

Fig. 1 (a) Map of the Nechako River Basin (NRB) upstream of Vanderhoof, British Columbia, Canada. (b) Map of land uses and sampling sites within the study area (part of the NRB not drained by major lakes). The inset map shows central and western Canada only and the location of the NRB within British Columbia. In (a), blue squares denote

communities and red stars denote hydrological features. Outflow from the reservoir is via the Skins Lake spillway and Cheslatta Falls, not the Kenney Dam. The Nautley River drains the large Fraser Lake sub-basin and is confluent with the Nechako River downstream of Fort Fraser; this sub-basin contains several large lakes

area is dominated by pine and spruce forests (Dorcey and Griggs 1991).

The study area was limited to the NRB located upstream of the community of Vanderhoof (Fig. 1) where the sturgeon recruitment failure has been the most drastic, and where there are important spawning areas, thus delimiting a watershed of $25,200 \mathrm{~km}^{2}$. In this part of the river basin, the most urbanized areas are Vanderhoof (pop., $~ 4440$ inhabitants) and Fort Fraser (pop., $\sim 500$ inhabitants), with the rest of the population living in sparse settlements. Forestry has historically been the main anthropogenic activity in the NRB but over the past 20 years, mountain pine beetle infestations have had a severe impact on the tree cover. Frequent forest fires occur in the NRB; the most significant recent events prior to 2015 occurred in 2010 in the Cheslatta Lake area $\left(2916 \mathrm{~km}^{2}\right.$ burned) and near Cut Off Creek in 2004 (104 km² burned). Also, large areas of forest have been cleared for agricultural activity (Nener and Wernick 2000; Picketts et al. 2017). As described above, the main anthropogenic impact on water and sediment dynamics within the Nechako River is the Kenney Dam, which was built in the early 1950s, and the subsequent water management policies. Mean annual air temperature in the ba$\sin$ is $3.7^{\circ} \mathrm{C}$ and mean annual total precipitation is $601 \mathrm{~mm}$ of which about one third falls as snow (Benke and Cushing 2005; Albers et al. 2016). Peak river discharges at Vanderhoof (up to $\sim 600 \mathrm{~m}^{3} \mathrm{~s}^{-1}$ ) occur during the snowmelt period, which typically occurs in late May or early June, although flows can be high after this period due to releases from the reservoir (Albers et al. 2016). The annual average discharge at Vanderhoof (Water Survey of Canada hydrometric station 08JC001) was $3.3 \times 10^{9} \mathrm{~m}^{3}$ year $^{-1}$ (1981-2015).
To investigate the fine-sediment sources and dynamics within the river basin, soil, channel bank, and suspended sediment samples were collected throughout the basin, along with a sediment core near Vanderhoof (Fig. 1). To limit the spatial extent of the study area given the large size of the basin, the four major lakes/ reservoirs in the study area were assumed to act as sediment sinks, supplying limited amounts of sediment to the downstream Nechako River. Such an assumption is supported by previous studies showing that limited amounts of sediment were transported downstream of the outlet of lakes with long residence times (Kemp et al. 1978; Colman and Foster 1994). The water from the Nechako Reservoir is delivered to the Nechako River through the Skins Lake spillway and via Cheslatta Falls upstream of the confluence with Cut OffCreek (site N@CO, Fig. 1); water is not released via the Kenney Dam.

\subsubsection{Suspended sediment}

Six suspended sediment sampling sites were selected along the Nechako River main stem (Table 1). Two of the sites were located just upstream (N@TB) and downstream (N@DO) of the Nautley River inflow in order to determine any change in the geochemical signature of suspended sediment due to inputs from the Fraser Lake sub-basin (Fig. 1). Six of the main tributaries of the Nechako River were also sampled to cover a range of land uses (Table 1, Fig. 1) from primarily forested (e.g., GREE, TARG) to those with moderate (e.g., SMIT) or large areas cleared for agriculture (e.g., CLEA, STON, MURR). The selected sub-basins also displayed a large range of physiographic conditions from high and steep sub-basins in the uppermost part of the NRB to flatter, lowland sub-basins 
Table 1 Main characteristics of the study sites and their sub-basins

\begin{tabular}{|c|c|c|c|c|c|c|c|c|c|}
\hline Location & Site & River & $\begin{array}{l}\text { Drained area* } \\
\left(\mathrm{km}^{2}\right)\end{array}$ & $\begin{array}{l}\text { Elevation } \\
(\mathrm{m})\end{array}$ & $\begin{array}{l}\text { Slope } \\
(\%)\end{array}$ & $\begin{array}{l}\text { Forests }^{\mathrm{a}} \\
(\%)\end{array}$ & $\begin{array}{l}\text { Exposed areas }^{\mathrm{ab}}(\%)[\% \\
\text { agriculture] }\end{array}$ & $\begin{array}{l}\text { Water bodies }{ }^{\mathrm{a}} \\
(\%)\end{array}$ & $\begin{array}{l}\text { Other }^{\text {ac }} \\
(\%)\end{array}$ \\
\hline \multirow{6}{*}{$\begin{array}{l}\text { Nechako main } \\
\text { stem }\end{array}$} & N@CO & Nechako & 153 & 888 & 10.9 & 79.3 & $11.4[0.6]$ & 2.4 & 1.3 \\
\hline & N@GR & Nechako & 1319 & 994 & 12.0 & 82.6 & $9.0[0.5]$ & 3.1 & 1.4 \\
\hline & N@TB & Nechako & 1915 & 943 & 11.8 & 80.5 & 10.9 [1.3] & 3.4 & 1.5 \\
\hline & N@DO & Nechako & 1939 & 940 & 11.8 & 76.3 & $13.1[1.4]$ & 2.8 & 2.2 \\
\hline & N@27 & Nechako & 2570 & 906 & 10.6 & 75.2 & $14.6[2.5]$ & 2.8 & 2.3 \\
\hline & N@VA & Nechako & 3364 & 890 & 9.6 & 74.1 & $15.6[3.6]$ & 2.9 & 2.4 \\
\hline \multirow[t]{6}{*}{ Tributaries } & GREE & Greer & 396 & 1087 & 10.9 & 88.4 & $3.8[0.6]$ & 5.0 & 1.3 \\
\hline & TARG & Targe & 345 & 1008 & 14.1 & 83.0 & $8.6[0]$ & 3.0 & 1.8 \\
\hline & SMIT & Smith & 274 & 871 & 11.9 & 70.0 & $20.0[3.3]$ & 6.4 & 2.1 \\
\hline & CLEA & Clear & 99 & 815 & 5.1 & 66.2 & $29.8[14.4]$ & 2.8 & 3.0 \\
\hline & STON & Stoney & 625 & 850 & 6.7 & 61.8 & $26.1[15.0]$ & 4.0 & 3.3 \\
\hline & MURR & Murray & 121 & 770 & 5.0 & 52.0 & $42.4[30.7]$ & 2.5 & 4.4 \\
\hline
\end{tabular}

*Drained areas do not include areas located upstream of the major lakes

${ }^{\mathrm{a}}$ From Owens et al. (2019)

${ }^{\mathrm{b}}$ Exposed areas include agricultural land, shrubland, and grassland

${ }^{\mathrm{c}}$ Other includes urban areas, roads, and other naturally occurring non-vegetated surfaces

near Vanderhoof (Fig. 1). Sub-basin areas and boundaries were determined with ArcMap 10.5 with the ArcHydroTool extension. Mean elevations and terrain slopes were determined from a provincial digital elevation model, and landuse patterns were determined using the Vegetation Resource Inventory (Agriculture and Agri-Food Canada 2017; BCFLNRORD 2018a, b).

Suspended sediment was collected at all sites over the period March to November 2015. Sampling frequency changed from bi-weekly collection in spring and summer (high-flow periods) to monthly collection during autumn (low-flow period). Suspended sediment samples $(N=175)$ were collected with time-integrating sediment samplers: see Phillips et al. (2000) and Smith and Owens (2014b) for details on design and operation. The samplers were placed approximately $30 \mathrm{~cm}$ above the river bed and tied to the shore. At the tributary sites, samplers were placed far enough upstream from the main stem to prevent back flooding. Suspended sediment from the traps was collected and placed into clean plastic buckets, left to settle for $48 \mathrm{~h}$, decanted, oven-dried at $105^{\circ} \mathrm{C}$ for $24 \mathrm{~h}$, and stored for further processing.

\subsubsection{Sediment core}

In September 2014, a sediment core was collected from an island within the main stem of the Nechako River, at Vanderhoof (between sites N@VA and STON, Fig. 1), that undergoes annual flooding. The core tube (1-m long, $10-\mathrm{cm}$ internal diameter) was manually inserted into the fine overbank sediments and removed with a spade. The sediment core was frozen for subsequent processing. The 81-cm-long sediment core was sliced in 1-cm layers. Each layer was dried at $105^{\circ} \mathrm{C}$ in an oven for $24 \mathrm{~h}$ and sieved at $63 \mu \mathrm{m}$ to determine the fine-sediment mass before being processed further.

\subsubsection{Source samples}

Soil sampling sites were selected across the investigated area to cover the range of land uses: (i) native forest, (ii) burned forest, (iii) logged forest, (iv) cropland, (v) straw (i.e., hay) fields, and (vi) grasslands and pasture. Composite samples were collected using a stainless steel hand corer. At each site, topsoil (upper $10 \mathrm{~cm}$ of soil) and subsoil (> 15-cm depth) samples were collected separately to investigate potential changes in geochemical signature with depth. Soil samples $(N=78)$ were collected during June and July 2015. Channel bank samples were collected along the Nechako River main stem from three main areas undergoing active bank erosion: $10-\mathrm{km}$ and $6-\mathrm{km}$ lengths of cut banks (also called river cliffs; bank heights up to $10 \mathrm{~m}$ ) located upstream and downstream of the N@GR sampling site, respectively, and $10 \mathrm{~km}$ of active floodplain erosion (bank heights 1-3 m) located upstream of the N@27 sampling site (Fig. 1). Tributary bank samples were also collected at locations close to suspended sediment and soil sampling sites. At each site, five bank samples were collected using a stainless steel corer inserted horizontally into the banks from 0 to $2 \mathrm{~m}$ above highwater level and they were combined into a composite sample, so as to get a representative sample. Altogether, 39 river bank samples were collected during July and 
August 2015. Both soil and bank samples were dried and sieved at $63 \mu \mathrm{m}$.

\subsection{Geochemical and fallout radionuclide analyses}

\subsubsection{Geochemical elements}

Suspended and floodplain sediment, soil, and channel bank samples were analyzed to quantify their geochemical signature (total labile metals/metalloids) using inductively coupled plasma-mass spectrometry (ICP-MS; Agilent Technologies $7500 \mathrm{cx}$ Series) at the University of Northern British Columbia's (UNBC) Northern Analytical Laboratory Services (NALS) facility. Approximately $150 \mathrm{mg}$ of material was weighed into glass tubes with metal-grade acids $(3 \mathrm{~mL}$ 15.6 $\mathrm{M} \mathrm{HNO}_{3}+1.5 \mathrm{~mL} 12.1 \mathrm{M} \mathrm{HCl}$; both BDH Aristar Plus). The digestion sequence consisted of a pre-digestion at room temperature for $20 \mathrm{~min}$ with periodic shaking, then a microwave-assisted digestion at $180{ }^{\circ} \mathrm{C}$ under 50 -bar pressure. Final digestates were diluted with Type- 2 water to $15 \mathrm{~mL}$ and stored at $4{ }^{\circ} \mathrm{C}$ until analysis by ICP-MS. Quality control was undertaken by running a duplicate split, a 100-ppb multi-element standard, a method blank, and a certified reference material (either National Research Council HISS-1 [Hibernia Shelf, Newfoundland] or PACS-2 [Esquimalt Harbour, British Columbia]) every 11 samples. For detailed analytical procedures, see Owens et al. (2019).

\subsubsection{Fallout radionuclide analyses}

To date the floodplain sediment core, cesium- $137\left({ }^{137} \mathrm{Cs}\right.$; halflife 30.2 years $)$ and excess lead-210 $\left({ }^{210} \mathrm{~Pb}_{\mathrm{XS}}\right.$; half-life 22.3 years) were measured. Cesium- 137 is an artificial radionuclide that was released into the atmosphere and was deposited through wet and dry fallouts onto surface soils and sediments after thermonuclear bomb tests conducted in the 1950s and 1960s. It was also released into the atmosphere after nuclear power plant accidents (i.e., Chernobyl in 1986, Fukushima-Dai-ichi in 2011), although radioactive fallout due to these accidents is generally negligible in most parts of Canada compared to bomb-derived fallout (Joshi 1986, 1988; Smith et al. 1993). Lead-210 is supplied to soils through the decay of both geogenic ${ }^{238} \mathrm{U}$ and atmospheric ${ }^{222} \mathrm{Rn}$. The atmospheric source supplies additional activity (i.e., ${ }^{210} \mathrm{~Pb}_{\mathrm{XS}}$ ) through rainfall. Both radionuclides quickly sorb onto, and remain tightly bound on, soil and sediment particles (Mabit et al. 2014) providing a means to reconstruct the history of sediment deposition at sites that undergo regular sedimentation (Mabit et al. 2014). Thus, the layer in the sediment core with the maximum value of ${ }^{137} \mathrm{Cs}$ activity matches the time of maximum atmospheric fallout in 1963 , while ${ }^{210} \mathrm{~Pb}_{\mathrm{XS}}$ allows the quantification of sediment deposition rates over $\sim$ 100 years (i.e., five half-lives). Samples were packed into
4-mL pre-weighed polyethylene containers and sealed airtight for 21 days (for details, see Mabit et al. 2014). The ${ }^{137} \mathrm{Cs}$ and ${ }^{210} \mathrm{~Pb}_{\mathrm{Xs}}$ activities in the samples were determined by gamma spectrometry using very-low-background HPGe detectors in the Department of Soil Science at the University of Manitoba, Winnipeg, Canada. The ${ }^{210} \mathrm{~Pb}_{\mathrm{Xs}}$ activity concentrations were estimated as the difference between the total ${ }^{210} \mathrm{~Pb}$ and ${ }^{226} \mathrm{Ra}$ activities and the Constant Rate of Supply (CRS) method was used to establish the core chronology (Appleby and Oldfield 1992).

The sediment layers in the floodplain core were also analyzed for organic matter content (by loss-on-ignition) and particle size distribution using a Malvern Mastersizer 3000 laser diffraction analyzer, at NALS, after the removal of organic matter by hydrogen peroxide, and chemical and ultrasonic dispersion.

\subsection{Mixing model and statistical tests}

All statistical tests and the mixing model runs were undertaken using $\mathrm{R}$ software (v. 3.4.4; $\mathrm{R}$ Core Team 2016) with the Rstudio interface (v. 1.1.453). Differences in tracer distribution were assessed using the KruskalWallis $H$ test: kruskal.test in R. To evaluate the differences between the source geochemical signatures, discriminant function analysis (DFA) was carried out using the ade 4 package and the significance was tested using multivariate analyses of variance (MANOVA): manova function in the MASS package. Relations between parameters were assessed using the Spearman method of the function cor.test in R.

The mixing models were created using the MixSIAR function (v. 3.1.9) from the MixSIAR R package (Stock and Semmens 2016a). MixSIAR is a Bayesian mixing model framework that was originally designed to estimate the proportion of prey sources ingested by a predator based on biological tracer data; for a detailed description, see Parnell et al. (2013). The effectiveness of Bayesian sediment fingerprinting models to estimate the proportion of sediment sources based on geochemical signatures has been demonstrated in several previous studies (e.g., Koiter et al. 2013a; Cooper and Krueger 2017; Blake et al. 2018; Liu et al. 2018) and they have been evaluated positively by Davies et al. (2018). The probabilistic Bayesian hierarchical model with Markov Chain Monte Carlo (MCMC) sampling was run using the JAGS software (Just Another Gibbs Sampler; v. 4.3.0; Plummer 2003) interfaced with the $\mathrm{R}$ software. An uninformative prior was used assuming that the proportions of each source were the same (Ward et al. 2010). The distribution for the sediment data was not known as only one suspended sediment sample was collected per site and per sampling date; consequently, the error structure in 
MixSIAR was set to "process only," therefore assuming a fixed variance based on the variance of the source (Stock and Semmens 2016b). Geochemical elements for which contents were below the limit of quantification (LOQ) for $10 \%$ of the samples from at least one sample type (i.e., suspended sediment, sediment core, forests, agricultural lands, channel banks) were deemed to be unreliable as potential tracers. For the remaining elements (i.e., B, $\mathrm{Na}, \mathrm{Mg}, \mathrm{Al}, \mathrm{P}, \mathrm{Ca}, \mathrm{V}, \mathrm{Cr}, \mathrm{Mn}, \mathrm{Fe}, \mathrm{Co}, \mathrm{Cu}, \mathrm{Zn}, \mathrm{Ga}, \mathrm{Ge}$, $\mathrm{Rb}, \mathrm{Sr}, \mathrm{Ba}, \mathrm{La}, \mathrm{Ce}, \mathrm{Pr}, \mathrm{Nd}, \mathrm{Sm}, \mathrm{Eu}, \mathrm{Gd}, \mathrm{Dy}, \mathrm{Er}, \mathrm{Ub}, \mathrm{Pb}$, $\mathrm{Th}, \mathrm{U})$, concentrations $<$ LOQ were replaced by LOQ/ $\sqrt{ } 2$.

Tracers were selected using Kruskal-Wallis comparisons and range tests to ensure significant differences between the sources, and that sediment tracer values were within the ranges observed for the sources. Discrimination factors were set to zero under the assumption that no enrichment occurred during erosion and sediment transport. All mixing models were run for 1,000,000 iterations with a 500,000 sample burn-in and a jump length of 500 to minimize autocorrelation between runs. Model convergences were tested using the Gelman-Rubin and Geweke diagnostics (Gelman and Rubin 1992; Geweke 1992; Brooks and Gelman 1997). Fingerprint property concentrations were not corrected for organic carbon content nor for particle size differences as previous studies concluded that the use of untested correction factors may lead to unreliable or erroneous results (Koiter et al. 2013a, 2018; Smith and Blake 2014; Laceby et al. 2017). Moreover, no statistical difference in carbon content and particle size was observed between suspended sediment and source samples (Mann-Whitney test: $p$ value $>0.7$ ). Uncertainties in source apportionment results were provided by MixSIAR and are standard deviations (see Electronic Supplementary Material).

\subsection{River discharge and precipitation data}

Temporal changes in sediment sources for the Nechako River main stem and tributary sampling sites for the 2015 season were compared to water discharge measured in the Nechako River at the main inlets (Cheslatta Falls and Nautley River) and at the outlet (Vanderhoof) of the study area. The discharges were measured at the Water Survey of Canada hydrometric gauging stations 08JA017, 08JB003, and 08JC001. The investigation on the influence of the variations in Nechako River discharge on the sediment sources at Vanderhoof since the 1950s was also based on the Water Survey of Canada archived hydrometric data at gauging station 08JC001. In order to investigate the influence of rainfall events, changes in source contributions were compared to the average rainfall amounts over the study area. These were estimated as the mean value of the rainfall measured at five Environment and Climate Change Canada weather stations at Vanderhoof, Burns Lake, Fort St. James, Ootsa/Skins
Lake, and Prince George (climate station IDs: 1098D90, 1091174, 1092970, 1085836, and 1096439, respectively).

\section{Results and discussion}

\subsection{Source discrimination and tracer selection}

Figure 2a shows the results of the DFA to discriminate between the various sources. Small differences were observed between the bank samples collected within the Nechako River and within tributary streams (MANOVA: $p>0.01$ ), and it was assumed that this geochemical signature matched the local geological background signature. Consequently, given the similarity between the two categories of bank samples, they were combined into a single source pool named "banks." No significant differences between native forests, lands used for wood production and regularly harvested, and lands that underwent forest fires were observed based on their geochemical properties (MANOVA: $p>0.01$ ). There is a suggestion that forest soils that were subjected to wildfire are slightly different; however, the sample size is low. Thus, these soil samples were merged into one single source category named "forests." Figure 2a also shows the soil samples classified as agricultural land, including croplands, grasslands, and straw fields. Most of these areas were characterized by regular plowing. Again, no significant differences were observed suggesting either that these land uses did not lead to changes in the geochemical signature or that the crop rotations were regular enough to conceal these changes (MANOVA: $p>0.01$ ). Consequently, these three categories were merged into a single source named "agricultural lands."

Discriminant Function Analysis was used to examine the differentiation between the three (revised) source groups (Fig. 2b). Although the selection of suitable tracers by DFA is not required to use MixSIAR, this method highlights the differences between the three source groups that were found to be significantly different (MANOVA: $p<0.001$ ). To select the best set of tracers, all parameters underwent "range tests" (e.g., Laceby et al. 2017) to compare tracer contents in the sediment (core and suspended sediment) samples with those for the source samples (i.e., agricultural lands, forests, and channel banks). Although phosphorus (P) passed the range test, this element was not kept because it has been previously reported to be a non-conservative fingerprint property in many situations, especially in depositional areas (Owens et al. 1999; Koiter et al. 2013b). Potential tracers were also tested for significant differences (Kruskal-Wallis test: $p<0.01$ ) that would permit sediment sources to be apportioned between land uses and also sub-basins. Consequently, 15 tracers were selected to run the mixing model: $\mathrm{Al}, \mathrm{Ba}, \mathrm{Ca}, \mathrm{Ce}, \mathrm{Dy}, \mathrm{Er}, \mathrm{Gd}$, La, Nd, Pb, Pr, Sm, Sr, Yb, and U (Fig. 3). 
Fig. 2 Discriminant Function Analysis (DFA) of source samples: a initial groups and $\mathbf{b}$ revised groups
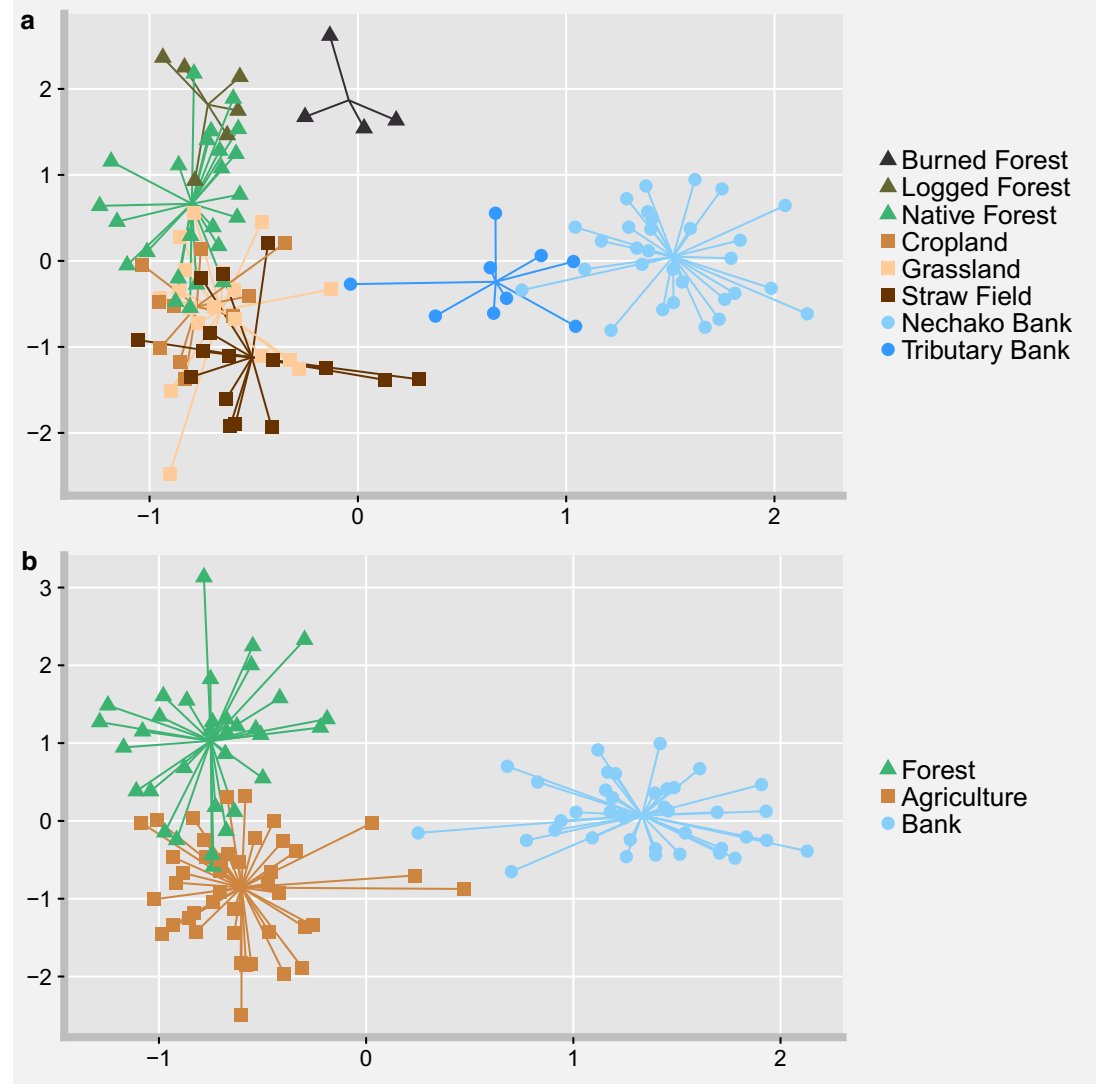

Among the fingerprint properties, 13 displayed significant variations between channel banks and agricultural lands, 12 differentiated between channel banks and forests, and 10 showed contrasting values between agricultural and forested lands. For $\mathrm{Ba}$ and heavier elements, the maximum contents were systematically measured in channel bank samples, while the highest contents for $\mathrm{Al}, \mathrm{Ca}$, and $\mathrm{Sr}$ were measured in forests. For all other elements, the lowest concentrations were measured in forest samples. There were no differences in the property concentrations between topsoils and subsoils in agricultural areas (Mann-Whitney test: $p>0.05$ ), probably due to the plowing process. However, for forested areas, among the 15 selected fingerprint properties, $\sim 50 \%$ (Ca, Ce, Dy, Gd, $\mathrm{Nd}$, $\mathrm{Pr}, \mathrm{Sm}$, and $\mathrm{Sr}$ ) showed contrasting concentrations between the surface and the subsoil horizons. These changes were mainly due to the frequent presence of very low values in topsoil, while the property concentrations appeared to be more homogeneous in subsoil horizons. For both agricultural and forested areas, topsoil and subsoil samples were combined as a single source type for each land use. The 15 fingerprint properties were used within the MixSIAR mixing models. All models passed the Gelman-Rubin convergence test as all the potential scale reduction factor (PSRF) values were $<1.05$, thereby demonstrating that the Markov chains were long enough.

\subsection{Suspended sediment sources during the 2015 field season}

As the sediment fluxes at each sampling site were not available, the following changes are only relative and must be used with caution. More detailed information on the uncertainties for all sampling sites can be found in the Electronic Supplementary Material.

\subsubsection{Seasonal trends in the source contributions}

During the entire 2015 sampling period, channel banks were found to be the dominant sediment source for all the main stem sampling sites and most of the tributary streams (Fig. 4). However, several contrasting trends were observed depending on the location of the site along the Nechako River or within the river basin.

N@CO This site exhibited considerable variability which can be explained by its upstream location. Until June, forested areas were found to be the main source of sediment except for two sampling periods at the end of April and in early May when an increase in supply from channel banks was observed. This drastic change coincided with a sharp rise in river 
Fig. 3 The distribution of the 15 geochemical elements selected as fingerprints to run the mixing model for the three sources: a channel banks, b agricultural land, and $\mathbf{c}$ forested land. To allow the plotting of all element contents on the same figure, content values were normalized by the maximum value measured in all source samples. Colored area covers the range of element contents measured in sources and the thick line represents the average value. Solid and dotted black lines, respectively, represent the average and the extreme values measured in sediment (suspended and core)
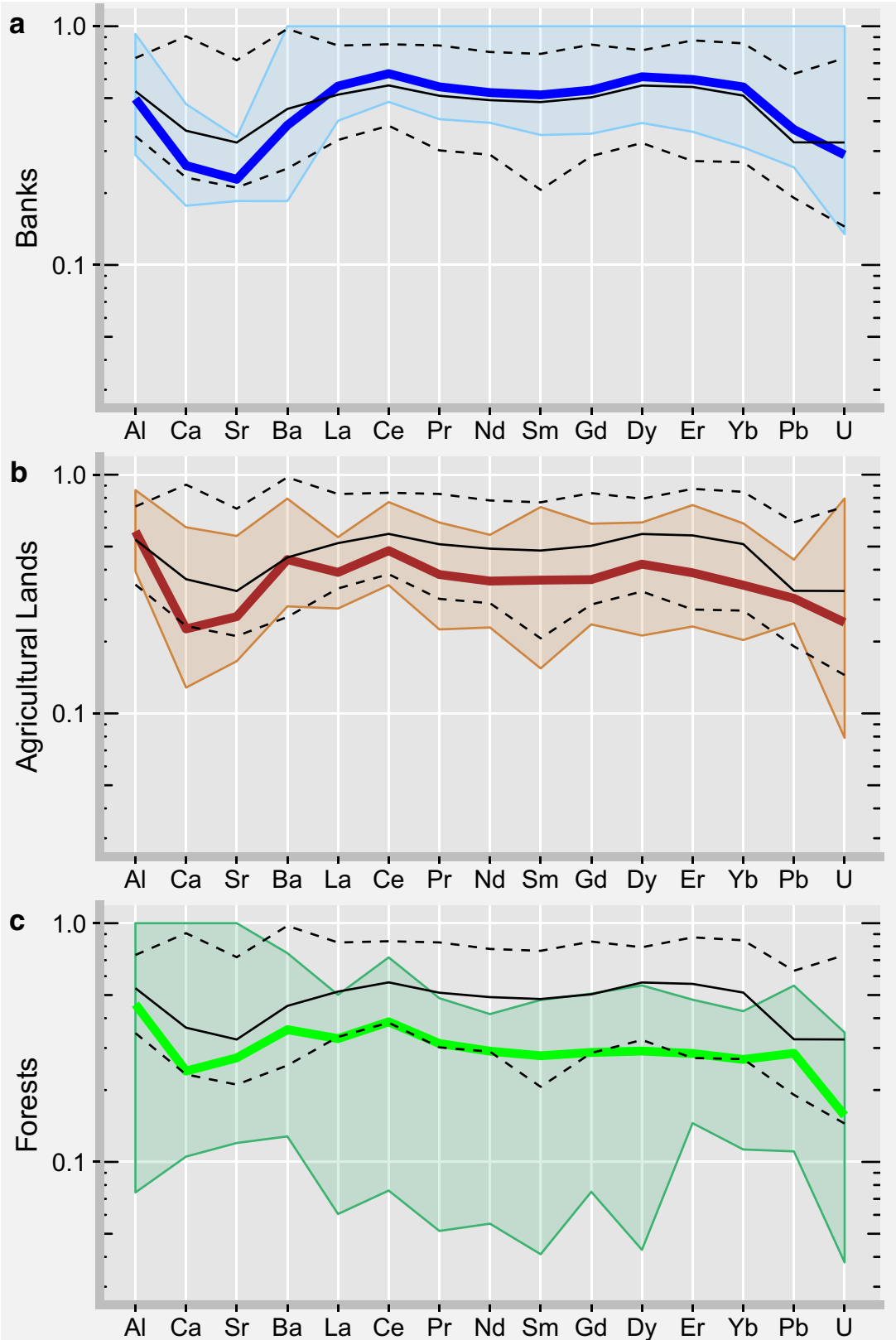

discharge (from 138 to $270 \mathrm{~m}^{3} \mathrm{~s}^{-1}$ ) that resulted from water releases at the Skins Lake spillway. From late June to midAugust, channel banks and forested areas supplied similar proportions of sediment, while agricultural lands had a very limited influence. This high value of the contribution from forest soils, which are usually reported as less erodible (Morgan 2005; Nearing et al. 2005; Borrelli et al. 2017), might be explained by the large portion of burned forests since large fires in 2010 destroyed $2916 \mathrm{~km}^{2}$ of forest north of Cheslatta Falls and Skins Lake. The storage of sediment eroded from burned forest soils in the Cheslatta system could also explain the peak of sediment from forest sources measured at $\mathrm{N} @ \mathrm{CO}$ during the flood peak in late May and early June as this material could be remobilized by the large flows of water $\left(515 \mathrm{~m}^{3} \mathrm{~s}^{-1}\right)$ released from the reservoir into the Nechako River through Cheslatta Lake. The noticeable increase in forest sources in late May and early June may also reflect a moderate rainfall event $\left(>14 \mathrm{~mm} \mathrm{day}^{-1}\right)$ at this time. From mid-August to October, channel banks were the main contributors to the suspended sediment load at this site. However, during this period, water flows in the Nechako River had dropped to $\sim 30 \mathrm{~m}^{3} \mathrm{~s}^{-1}$, suggesting that limited amounts of sediment were eroded from the channel banks and that this change in sediment origin might instead be due to the lack of surface erosion of forested or agricultural soils, as only a few days had rainfall totals $>5 \mathrm{~mm} \mathrm{day}^{-1}$. 
Fig. 4 Temporal changes in the sources of suspended sediment collected at the 12 sampling sites in 2015, expressed as a percentage (vertical axis): blue is channel banks, brown is agricultural land, and green is forested land. Results for the main stem sites are plotted in the left column and ordered in a downstream direction. Results for the tributary sites are plotted in the right column following the same upstream to downstream order (see Fig. 1 for site locations and Electronic Supplementary Material for details on the uncertainties associated with each sample). Due to sampling difficulties, only three sediment samples were collected at the TARG site

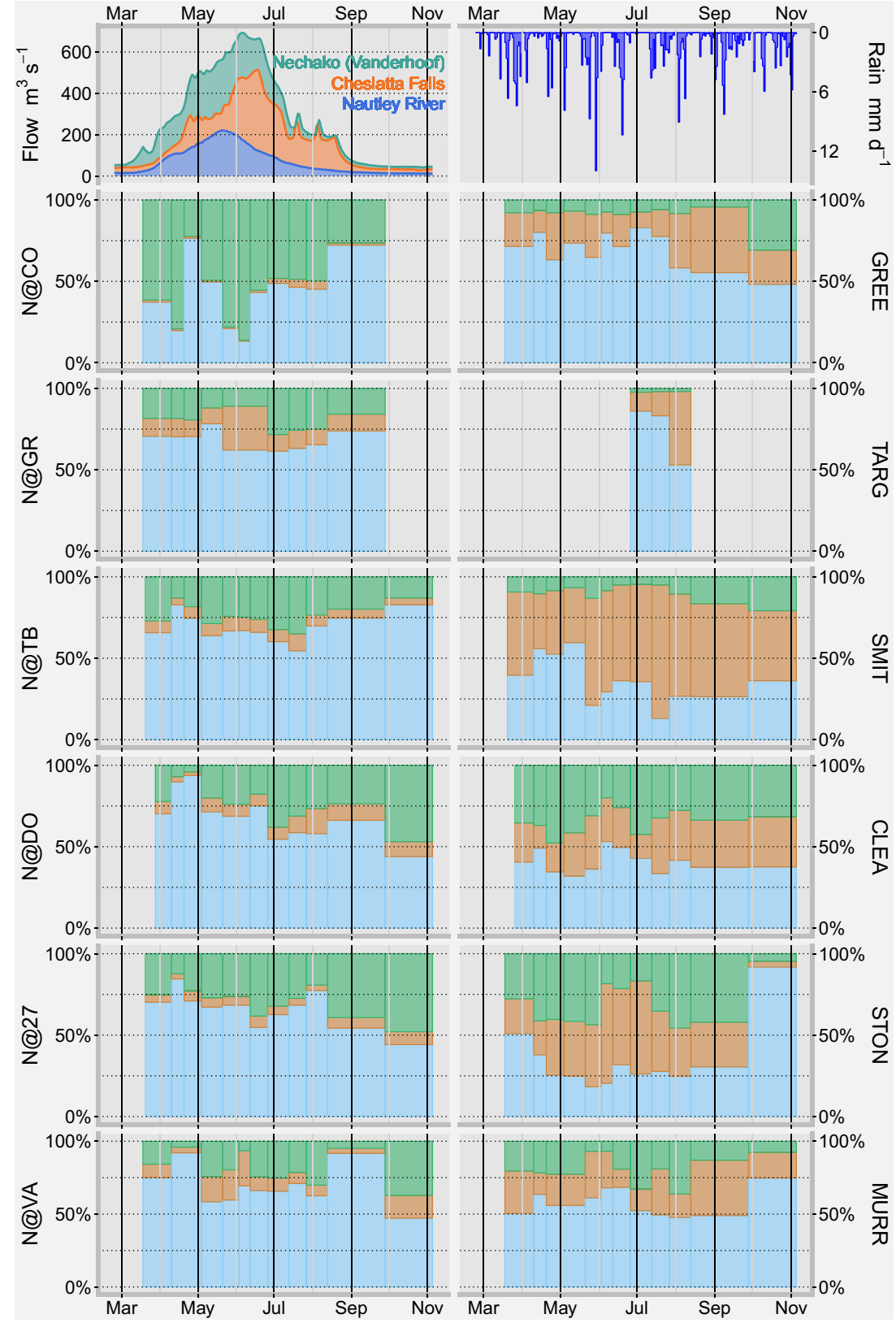

N@GR and N@TB Similar patterns were observed for these two sampling sites. Over the sampling period, the changes in sediment sources were less significant than those recorded at N@CO. The geochemical signature of suspended sediment remained relatively constant from March to July, except for a few changes. For both sites, a slight increase in channel bank contribution was observed between late April and early May. This period matched the rapid rise in water level due to water releases from the reservoir, suggesting that a rapid change in water depth might lead to bank instability and erosion (Julian and Torres 2006; Chen et al. 2017). During late May and June, a rise in sediment supply from agricultural areas was observed, although only at N@GR, which might reflect the greater rainfall amounts during this time. The difference between sites cannot be explained by the differences in land use between the two sub-basins and it might be due to localized land management practices as agricultural contributions were higher at N@GR during the whole sampling period. For both sites, there was an increase in contributions from forest soils from March to July followed by a decrease until the end of the sampling period. This seasonal change in the sediment supply from forested areas could be related to the progressive change in the freshet from lowland agricultural areas to elevated forest areas that lasted until late July. Thus, the difference in mean elevation between both watersheds (Table 1) could explain why this phenomenon was observed until August in the upstream watershed. At the end of the sampling period (September to November), as with the N@CO site, 
there was a rise in the relative contributions from channel banks, likely due to similar reasons.

N@DO, N@27, and N@VA Similar patterns were observed for the three downstream sites on the Nechako River main stem. Channel banks were found to be the main source of sediment even though their relative supply to the sediment load generally decreased over the sampling period. The temporal changes in sediment source at N@DO were different from those observed at N@TB, therefore suggesting that sediment derived from the Fraser Lake sub-basin through the Nautley River had a significant impact on the composition of sediment carried in the downstream reaches of the Nechako River. Slight increases in channel bank contributions were observed during the period of rapid changes in river flow (late April and August). However, the changes in channel bank contributions were not synchronous for all the Nechako sampling sites suggesting that the various bank areas might have been undergoing active bank erosion at different times. Among the Nechako River main stem sampling sites, the most noticeable bank supply was observed at N@VA in August and September. Except for this, all three downstream Nechako sites displayed a continuous rise in contributions from forest sources that could be related to the progressive effect of the freshet on forested areas in the more remote, and higher, parts of the basin and/or the decline in the relative contributions from channel banks due to decreasing river flows in the latter part of the sampling period. For the proportion of sediment coming from agricultural areas at Vanderhoof, it was higher during May to early June, reflecting the freshet in the lower parts of the basin and the higher rainfall amounts, and in October.

GREE and TARG These two sub-basins have the smallest amount of cleared land (Table 1). High contributions due to channel bank erosion were measured during the period from March to late July which matches the freshet. This suggests that the rise in water level and the subsequent bank erosion led to a greater supply of material than from surface soil erosion by water released by snowmelt. During late July, there was a sharp rise in sediment contributions from agricultural areas at both sampling sites, which could reflect land management practices as well as a rainfall event of $\sim 10 \mathrm{~mm}$ day $^{-1}$ during the time that the sampler was deployed. At the GREE site, a rise in the relative proportion of sediment originating from forests was observed in October that might be due to a reduction of sediment supply from channel banks and agricultural areas.

SMIT, CLEA, STON, and MURR The four downstream subbasins have similar, lower elevations ( $\sim 800 \mathrm{~m}$ a.s.1.) and greater amounts of cleared land for agriculture and other land uses compared to the previous two sub-basins (Table 1). At the SMIT site, a continuous rise in contributions from forest sources was observed but the main contributor remained the agricultural lands, which reached its maximum between late May and late July. The proportion of sediment that originated from channel banks was higher at the beginning of the sampling period with a peak in May, then it decreased during the summer and started to increase during the autumn. This relative increase of channel banks may be due to lower supplies of sediment from forested and agricultural lands or may reflect autumnal rain events.

At the CLEA and STON sites, similar source contributions were determined at the start of the sampling period with channel banks accounting for $\sim 40 \%$ of the sediment load while the proportions of forested and agricultural areas were about the same $(\sim 30 \%)$. This result is consistent with the similarity of morphology and land uses (Table 1) in the two sub-basins. At the CLEA site, the proportion of each source was broadly similar over the sampling period. In June, the relative contributions from forests decreased without an obvious reason, whereas the rise in channel bank and agriculture land coincides with the freshet and the subsequent rise in water level. At the STON site, the temporal trend was very similar to that observed at the SMIT site. A larger contribution from channel banks was measured in March at the start of the freshet when river flows increased while the presence of a dense snowpack prevented surface soils from being eroded (Fu et al. 2010). Sediment contributions from surface soils started to increase in April and reached a peak in mid-summer when more than half the sediment was coming from agricultural lands, leading to a concomitant decrease in the relative contribution of channel bank material. The value of channel bank contributions during the last sampling period was unusually high $(>90 \%)$ and may be due to recent bridge building across the river approximately $2 \mathrm{~km}$ upstream of the sampling site. Remobilization of channel bed and bank material due to the construction could explain the rise in channel bank contributions.

At the MURR sampling site, the overall contribution of river banks to the sediment load was higher than that at comparable sampling sites (CLEA and STON). This difference may be due to local channel bank erosion near the sampler.

\subsubsection{Spatial trends in source contributions}

The estimation of the source contributions integrated over the sampling period provides a means to investigate spatial trends over the study area and to compare results for the Nechako River main stem with its main tributaries. As no data were available to quantify the sediment fluxes at the suspended sediment sampling sites, the average source contributions were estimated using the contributions quantified above weighted according to the sampling duration (Fig. 5). Thus, the time-averaged contributions must be interpreted as a 
Fig. 5 Time-averaged source contributions for suspended sediment samples collected in 2015 (values are means \pm 2 SD)

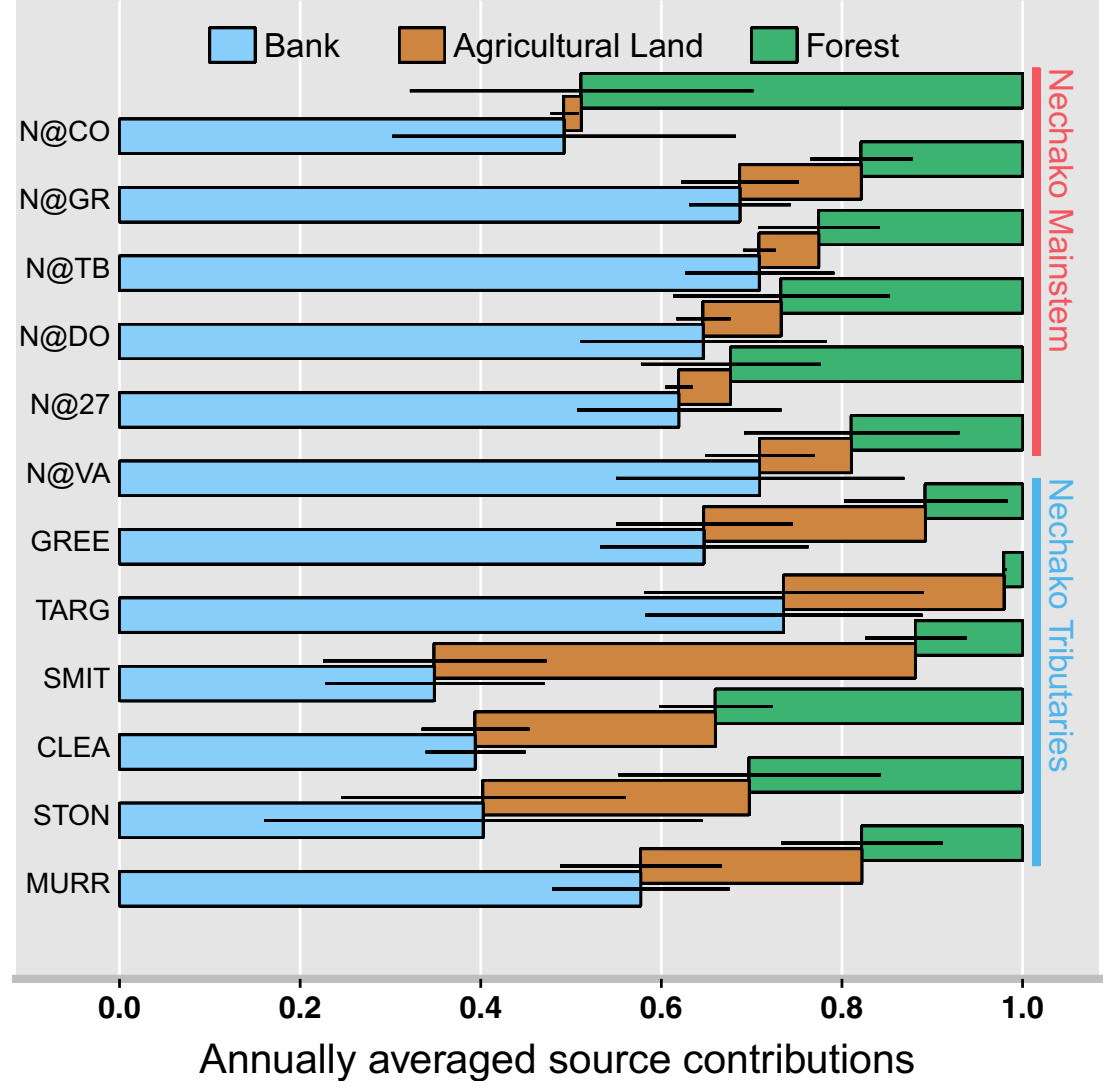

frequency of sediment supply rather than the actual contributions to the sediment flux. However, temporal changes in sediment origin at each site were generally limited, therefore suggesting that weighted-average contributions would be similar. However, caution should be exercised when interpreting these results.

In the case of the sites along the Nechako River main stem, the geochemical signature of the suspended sediment samples were similar except for the most upstream site (N@CO; Fig. $5)$. Thus, suspended sediment mainly originated from channel banks $(60-70 \%)$ with smaller amounts coming from forested areas (20-30\%) and agricultural lands (10-15\%). Regarding the contributions from channel banks, it was slightly higher at sampling sites located downstream of the active bank erosion areas (i.e., N@TB and N@VA) which were visually identified during the sampling campaign. The proportion of sediment from agricultural lands was surprisingly high at N@GR considering the limited surface area of this land use in the subbasin (Table 1). However, it was consistent with the abundance of sediment from agricultural soils determined for Greer Creek (i.e., the GREE site). It is important to note that the N@GR site was located downstream of the confluence of Greer Creek with the Nechako River and on the same bank. Consequently, heterogeneous mixing of sediment at the confluence might have led to an overrepresentation of sediment coming from Greer Creek. For N@DO and other downstream sites, the proportion of sediment coming from forested and agricultural areas increased with the relative surface area exploited for forestry and agriculture. This change might also be due to sediment supply from the Fraser Lake sub-basin through the Nautley River. Indeed, different sediment composition was observed at the sampling sites located upstream (site N@TB) and downstream (site N@DO) of the confluence of the Nautley and Nechako Rivers.

At the downstream site on the Nechako River main stem, there was an increase in contributions from channel bank sources compared to sites immediately upstream. This rise might be because the community of Vanderhoof is located downstream of an area of intense floodplain erosion, or it may reflect a one-time event as the mean value included a noticeably high value observed for the sample collected in late September, which encompassed the sampling period from mid-August to end of September (Fig. 4). This highlights the limits of using time-averaged values instead of values weighted by the actual sediment fluxes.

Among all main stem sites, the sediment collected from the $\mathrm{N} @ \mathrm{CO}$ site, which is located $13 \mathrm{~km}$ downstream of Cheslatta Falls (Fig. 1), had the most contrasting sources with similar contributions from channel banks and forests and minimal contributions from agricultural areas (Fig. 5). The strong 
relationship between water discharge at the Skins Lake spillway and sediment originating from forested areas (Fig. 4) suggests that remobilization of material stored on the bottom of Cheslatta Lake might be the main process driving sediment composition. Indeed, significant areas of the sub-basin contributing to the Nechako Reservoir were burned during a large wildfire in 2010 , potentially leading to a great supply of sediment from forest sources to the reservoir. The other source of sediment was the channel banks reflecting the importance of flow during the freshet and reservoir releases. The lack of sediment derived from agricultural lands was expected as they only cover a negligible surface area in the N@CO sub-basin (Table 1).

In terms of the average source contributions at the tributary sampling sites (Fig. 5), three groups could be distinguished based on their location. At the upstream sites (GREE and TARG), large contributions of channel banks (65-70\%) and agricultural lands $(\sim 25 \%)$ were observed but supplies from forested areas were surprisingly low $(\sim 5-10 \%)$. However, unlike downstream sub-basins, only a small portion of forests have been harvested and native forests have low erosion rates due to the dense vegetation cover (Morgan 2005; Nearing et al. 2005; Borrelli et al. 2017). Moreover, because of this vegetation cover, the freshet led to increased channel bank erosion rather than surface soil erosion. The amount of sediment originating from agricultural areas was significant in regard to the limited areas exploited for agriculture but the relatively steep slopes in these sub-basins might have led to higher erosion rates. This supply had a noticeable effect on the composition of sediment in the Nechako River downstream of Greer Creek (i.e., at N@GR).

The SMIT sampling site drained a sub-basin characterized by a larger amount of cleared land compared to CREE and TARG (i.e., similar to the more agricultural downstream subbasins) but with a steeper relief, similar to these two upstream tributary sites. Among all sites, the highest agricultural contribution was measured at the SMIT site suggesting that cropland erosion rates and sediment delivery strongly depend on the slope of the land.

Within the three downstream sub-basins, large portions of lands have been cleared for forest harvesting and agricultural activities (Table 1) leading to significant erosion of surface soils with contributions of $\sim 40-60 \%$, mainly related to the timing of snowmelt. The similarity of contributions from forested and agricultural lands might be explained by forestry activities (including salvage logging) following the mountain pine beetle outbreak, which started in the 1990s and persisted for several decades (NRC 2018) that made the soil more susceptible to erosion. At the MURR site, the high channel bank proportion $(\sim 60 \%)$ compared to CLEA and STON $(\sim 40 \%)$ might be due to local erosion processes as the agricultural lands are located in the uppermost part of this sub-basin and because eroding channel banks were observed immediately upstream of the sampling site.

\subsection{Historical changes in sediment sources based on a floodplain core}

A chronological framework of the sediment core layers was established based on short-lived fallout radionuclide activities (Fig. 6a, b). The plot of ${ }^{137} \mathrm{Cs}$ activity displayed two peaks at depths of $12 \pm 1 \mathrm{~cm}$ and $31 \pm 1 \mathrm{~cm}$ (Fig. 6a), which is common in many sediment cores collected in floodplains with regular overbank sediment supply in the Northern Hemisphere. The deepest peak correlates with the maximum of atmospheric fallout related to nuclear bomb tests (i.e., 1963; Abril 2004). The upper peak could be related to the Chernobyl nuclear plant accident in 1986 (Davison et al. 1993), although generally its occurrence in North America is believed to be minimal (Smith et al. 1993). The logarithmic plot of ${ }^{210} \mathrm{~Pb}_{\mathrm{xs}}$ versus depth (data not shown) displayed a general decrease, as expected, and led to an estimation of an average sedimentation rate of $6.2 \mathrm{~mm} \mathrm{year}^{-1}$ for the period since the early 1970s, which compares favorably with the ${ }^{137} \mathrm{Cs}$-based estimates detailed below. The fallout radionuclide activities did not provide useful information for the bottom part of the core as it was comprised of very heterogeneous sediment. In particular, a thick layer of coarse sediment was found between 38- and 69-cm depths. Due to its approximate date (early 1950s) and the coarse nature of the sediment at this depth, this layer was assumed to be related to the single reservoir filling event during which the Nechako River discharge at Vanderhoof dropped to $60 \pm 23 \mathrm{~m}^{3} \mathrm{~s}^{-1}$ for four successive years between 1953 and 1956: prior to this, winter flows were typically between 50 and $150 \mathrm{~m}^{3} \mathrm{~s}^{-1}$ and peaks during the freshet were of the order of $500 \mathrm{~m}^{3} \mathrm{~s}^{-1}$ (Hartman 1996). Because of the lack of accurate data to date the deepest part of the core, no attempt was made to match these layers to a specific year. This part of the core will be referred to as the pre-dam period. Overall, four periods were distinguished within the core.

Period 1 The layers between 81 and $70 \mathrm{~cm}$ constituted the predam period. Because it was not possible to date these layers, the sedimentation rate could not be estimated. During this period, the average organic matter content was $3.0 \pm 0.44 \%$ and the fine-sediment fraction $(<63 \mu \mathrm{m})$ accounted for $24 \pm$ $12 \%$ of the total mass of sediment. The main source of the $<$ $63 \mu \mathrm{m}$ fraction (i.e., not the bulk sediment) was determined to be the channel banks $(72 \pm 6 \%)$, followed by forests $(23 \pm 6 \%)$ and agricultural areas $(5 \pm 1.4 \%)$.

Period 2 The layers between 69 and $38 \mathrm{~cm}$ constituted the reservoir filling period characterized by a sharp decrease in water discharge. At this time, the deposition rate was estimated at $78 \mathrm{~mm} \mathrm{year}^{-1}$ leading to a rise in the channel bed elevation of $31 \mathrm{~cm}$ in four years. The fine-grained sediment mainly originated from the river with banks contributing $92 \pm 6 \%$, while forested and agricultural areas had negligible impacts. 


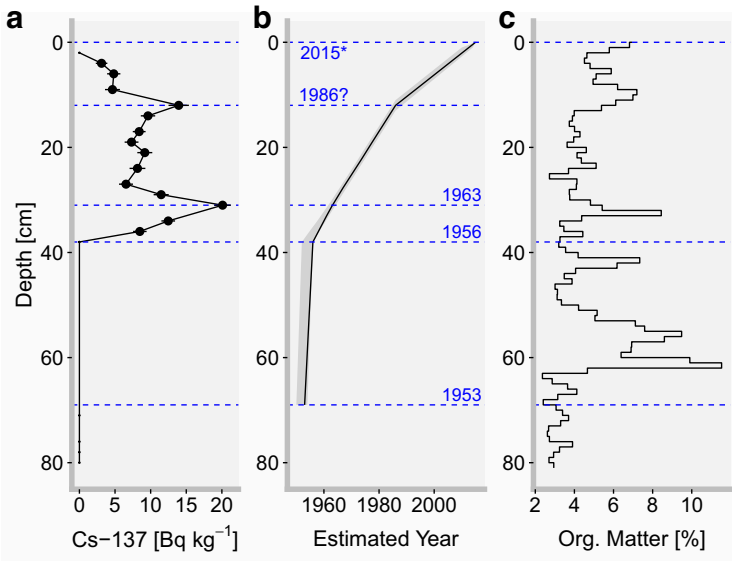

Fig. 6 Chronology and changes in sediment properties with depth in the sediment core collected at the basin outlet (site N@VA, see Fig. 1 for location). (a) ${ }^{137} \mathrm{Cs}$ activity concentration, (b) estimated age of the sediment layers based on ${ }^{210} \mathrm{~Pb}_{\mathrm{xs}}$ and ${ }^{137} \mathrm{Cs}$ activities, (c) organic matter content, (d) percentage in mass of the fine fraction $(<63 \mu \mathrm{m}),(\mathrm{e})$ relative

However, the sediment was coarse with the fine fraction accounting for only $7 \pm 2 \%$ of the total mass. The low flows could explain the rapid deposition of large amounts of coarse sediment. While the sediment particle size composition was fairly homogeneous in this layer, the organic contribution (average $5.1 \pm 2.4 \%$ ) appeared to be much more variable with three main peaks, with the highest $(\sim 12 \%$ during the peak at $62-\mathrm{cm}$ depth) being the maximum value measured in the core (Fig. 6c). This variation could result from the seasonality in aquatic vegetation both on the floodplain and in the river corridor. Indeed, the limited amount of cold water coming from the uppermost parts of the basin and the lower water depth may have led to higher water temperatures during summers, therefore increasing the biomass and the organic content of the sediment.

Period 3 The third period included the layers from 37 to $13 \mathrm{~cm}$ and covered approximately 30 years from the end of the reservoir filling $(\sim 1956)$ to the mid-1980s. The precise end of this third period could not be determined because changes in water management policy occurred at this time and the entire decade may have been a transition phase in the sediment dynamics of the river. During this third period, the floodplain deposition rate decreased to an average of $8.8 \mathrm{~mm}_{\text {year }}{ }^{-1}$. In these layers, the average content of organic matter was $4.3 \pm$ $1.1 \%$ and the proportion of fine sediment increased to $41 \pm$ $12 \%$. The contributions of sources also changed and forested and agricultural sources accounted for $24 \pm 11 \%$ and $6 \pm 3 \%$, respectively, while bank supply decreased to $70 \pm 14 \%$ (Fig. 6). From 1957 to the early 1970 s, the contribution of surface sources (forested and agricultural areas) was $40 \pm 14 \%$ (32\% and $8 \%$, respectively). These contributions are strongly related to the annual discharge (Spearman correlation test: $p<0.001$ ). McAdam et al. (2005) reported that floods during the 1957 to
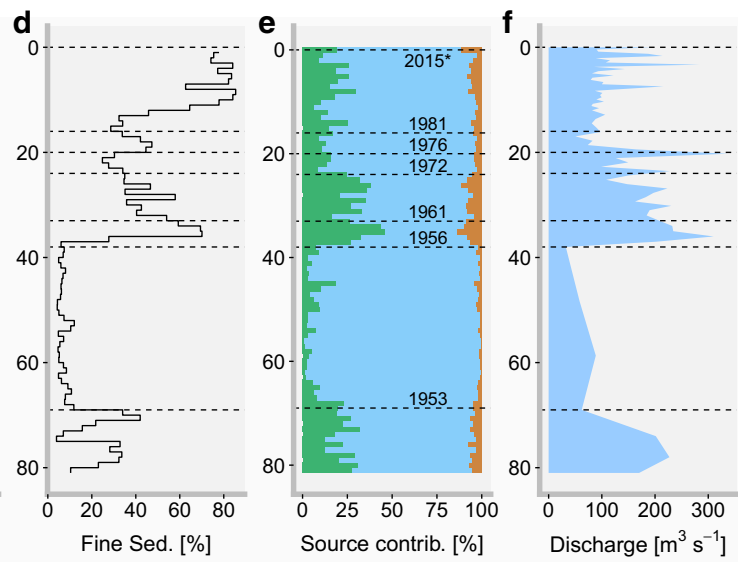

source contributions (green: forested land; blue: channel banks; brown: agricultural land), and (f) annually averaged water discharge based on estimated year. *Although the core was collected in 2014, 2015 values were based on the suspended sediment samples collected at N@VA during the 2015 sampling period

1970 period were mainly due to abundant freshets, which might explain the rise in sediment supply from forested and agricultural lands. However, freshets alone cannot explain the changes in the source contributions. As an example, the massive freshet of 1976 , with peaks flows of $745 \mathrm{~m}^{3} \mathrm{~s}^{-1}$ at Vanderhoof, had little effect on the apportionment of sediment from forested and agricultural areas. To understand these changes, one must take into account the massive supplies of channel bank sediment that occurred in the uppermost part of the watershed in 1961 and 1972 when the large amounts of water released at the Skins Lake spillway led to a bypass of Cheslatta Falls (Fig. 1), with the Cheslatta River carving out a new path to the Nechako River. The sediment mobilized during these two events amounted to $\sim 1 \times 10^{6} \mathrm{~m}^{3}$ (McAdam et al. 2005). These drastic modifications in the sediment balance of the Nechako River significantly changed the source signature for many years. Thus, the first event at Cheslatta Falls had a visible impact on the source contribution at Vanderhoof during the first two years (1961 and 1962) and during the two following major floods in 1964 and 1967 when the discharge reached $>550 \mathrm{~m}^{3} \mathrm{~s}^{-1}$. These two years also matched the timing of sturgeon recruitment failure. McAdam et al. (2005) suggested that the coarser fraction of the sediment derived from the erosion of the Cheslatta alluvium reached Vanderhoof in 1972. This hypothesis is supported by our results that show a sharp increase in the contribution of channel banks to sediment deposited at the floodplain site just upstream of Vanderhoof that remained at a high level for several years (Fig. 6e). These results show that the sources, and thus composition, of sediment can be changed for long periods of time following major disturbance events such as landslides or, as in this situation, the massive erosion of stored alluvial sediment due to channel bank (and bed) erosion. 
Period 4 The last period included layers from $12 \mathrm{~cm}$ up to the top of the core and covered approximately 28 years from the mid-1980s to 2014 when the core was collected. The average sediment deposition rate for this period was $4.3 \mathrm{~mm}$ year ${ }^{-1}$. This period is characterized by a rise in the proportion of fine sediment starting in the late 1980s (Mann-Kendall test: $p<0.01)$. This change could be related to the implementation of new water management policies that started in 1981 . These policies imposed a minimum water discharge downstream of the dam and a regulated discharge in order to maintain the water temperature below a $20{ }^{\circ} \mathrm{C}$ threshold level so as to protect aquatic biota, especially salmonids and the Nechako white sturgeon (Hartman 1996). These changes in water management resulted in modification of the annual hydrographs with more water being released during summer, from 20th July to 20th August each year. The new water policies could have changed the source and composition of the sediment recorded in the core. Since 1990, both the organic matter content and proportion of fine sediment have been significantly higher (Mann-Whitney test: $p<0.01)$ than those during the previous period (1972-1987). This could be related to the increase in cleared areas in the NRB from $\sim 500 \mathrm{~km}^{2}$ in the $1980 \mathrm{~s}$ to $1290 \mathrm{~km}^{2}$ in the 2000s (BCFLNRORD 2018b). However, the contribution of sediment from forests in the past few years remained lower than during the years following the completion of the dam suggesting that the rise in forested and agricultural lands might be compensated by the large supply of channel bank sediment from the Cheslatta Falls area.

Overall, a strong relationship was found between the proportion of fine sediment and the contribution of forested and agricultural sources (Spearman correlation test: $p<0.001$ ). This result suggests that surface erosion may lead to the supply of finer sediment to the river system, therefore changing the particle size of the sediment load. Consequently, the potential for channel bed clogging by fine-grained sediment, in addition to sands, might be related to the documented mortality of the Nechako white sturgeon (Hartman 1996) as the juveniles mainly feed on larvae for which the channel bed constitutes the main habitat (McAdam et al. 2005).

\section{Conclusions}

Over the 2015 sampling period, the changes in the water discharge of the Nechako River and the supply of sediment from the main tributaries were found to be the main factors driving the variations in the origin of the suspended sediment load. Thus, the results for 2015 were strongly impacted by the management of the water release from the Nechako Reservoir via the Skins Lake spillway. However, changes in sediment sources at tributary sampling sites mainly depended on the timing and magnitude of snowmelt from the various parts of the basin.

Regarding the time-averaged source contributions over the 2015 field season, the uppermost site on the Nechako River was unusual and results suggest that the large amounts of water released at the Skins Lake spillway were enough to remobilize bottom sediment from Cheslatta Lake and led to a higher forest source signature in downstream sediment. This geochemical signature could be related to the significant wildfire that occurred in the Cheslatta sub-basin during summer 2010, which may have caused sediment to be eroded from the hillslopes and be temporarily stored in the lake; however, further research is required to confirm this. For downstream Nechako River main stem sites, the main source of sediment was found to be the channel banks especially at sites located downstream of active cut banks or areas of the floodplain undergoing erosion. However, noticeable supplies from tributaries were observed; for example, the Nautley River contributed enough to the sediment load to change the composition at downstream Nechako main stem sites.

At downstream sites, an increase of the proportion of sediment coming from forested and agricultural lands was observed, which was consistent with the rise in the surface areas cleared for forest harvesting and agriculture. The contribution from agricultural areas also depended on the steepness of the basin with steeper slopes leading to higher erosion rates. However, not all variations in sediment sources could be easily explained through land use and landscape morphology; clearly, more detailed spatial information is required to better understand the sediment dynamics. The use of biomarkers and land use-specific properties (e.g., organopollutants) as sediment fingerprints (e.g., Reiffarth et al. 2016; Owens et al. 2019) could provide useful insight to improve the understanding of the dynamics of sediment erosion and transport within the NRB.

Regarding the historical results obtained from the sediment core, the completion of the Kenney Dam in the 1950s led to a drastic change in the sediment transport capacity of the Nechako River. Another significant temporal trend was the increase in the proportion of fine sediment measured in the most recent core layers. This change in sediment particle size was related to surface erosion and the contribution of forested and agricultural areas, which may have resulted in the clogging of river channel gravels. Consequently, this could explain the high mortality of white sturgeon juveniles as channel bed interstitial spaces constitute their prey's main habitats. If this assumption is correct, any recent or future increase in cleared areas resulting in an increase in fine-grained sediment supply to the channel network may put the white sturgeon population at further risk. After the completion of the dam, a shift in the proportion of sediment originating from forested and agricultural lands was observed due to the increase of cleared areas in the NRB. This was counterbalanced by the large supplies of sediment derived from the erosion of alluvial sources such as 
channel banks from Cheslatta Falls in 1961 and 1972, which has remained high since.

This study has used the sediment fingerprinting technique to demonstrate the complex response of river sediment dynamics over decadal timescales to multiple pressures associated with river regulation and land-use changes, in addition to episodes of wildfire and forest harvesting following mountain pine beetle outbreaks. Over annual timescales, temporal and spatial variations in sources are also driven by the location and timing of snowmelt. Future work in this basin will investigate additional years and utilize other fingerprinting properties to focus on specific river management and land-use activities, thereby helping to understand the role of cumulative effects in this "aquatic critical zone" (Bianchi and Morrison 2018).

Acknowledgments DG would like to acknowledge financial support from the French Academy of Sciences. Thanks are extended to Leticia Gaspar and Kristen Kieta (UNBC) and Emeline Herlet for assistance with the fieldwork; Erwin Rehl and Charles Bradshaw (NALS-UNBC) and David Lobb and Eva Slavicek (University of Manitoba) for laboratory support; Aseem Sharma for assistance with the climate data; and Wayne Salewski, June and Dennis Wood, and the Nechako White Sturgeon Conservation Centre for logistical support.

Funding information Financial support was provided by Nechako Environmental Enhancement Fund (NEEF) and BC Real Estate Foundation Partnering Fund grants.

Open Access This article is distributed under the terms of the Creative Commons Attribution 4.0 International License (http:// creativecommons.org/licenses/by/4.0/), which permits unrestricted use, distribution, and reproduction in any medium, provided you give appropriate credit to the original author(s) and the source, provide a link to the Creative Commons license, and indicate if changes were made.

\section{References}

Abril JM (2004) Constraints on the use of ${ }^{\mathbf{1 3 7}} \mathrm{Cs}$ as a time-marker to support CRS and SIT chronologies. Environ Pollut 129:31-37

Albers SJ, Déry SJ, Petticrew EL (2016) Flooding in the Nechako River Basin of Canada: a random forest modeling approach to flood analysis in a regulated river system. Can Water Resour J 41:250-260

Agriculture and Agri-Food Canada (2017) ISO 1913. Data product specifications: annual crop inventory. https://open.canada.ca/data/ dataset/cb3d7dec-ecc6-498b-ac17-949e03f29549. Accessed July 2018

Appleby PG, Oldfield F (1992) Application of lead-210 to sedimentation studies. In: Ivanovich M, Harmon RS (eds) Uranium-series disequilibrium: applications to earth, marine, and environmental sciences. Clarendon Press, Oxford, pp 731-738

BCFLNRORD (2018a) Forest vegetation composite polygons. BC Ministry of Forests, Lands, Natural Resource Operations and Rural Development, Forest Analysis and Inventory: VRI - https:// catalogue.data.gov.bc.ca/dataset/vri-forest-vegetation-compositepolygons-and-rank-1-layer . Accessed July 2018

BCFLNRORD (2018b) Harvested areas of BC (consolidated Cutblocks). BC Ministry of Forests, Lands, Natural Resource Operations and
Rural Development, Forest Analysis and Inventory: https:// catalogue.data.gov.bc.ca/dataset/harvested-areas-of-bcconsolidated-cutblocks. Accessed July 2018

Benke AC, Cushing CE (2005) Rivers of North America. Elsevier, New York

Bianchi TS, Morrison E (2018) Human activities create corridors of change in aquatic zones. EOS 99. https://doi.org/10.1029/ 2018EO104743

Blake WH, Boeckx P, Stock BC, Smith HG, Bodé S, Upadhayay HR, Gaspar L, Goddard R, Lennard AT, Lizaga I, Lobb DA, Owens PN, Petticrew EL, Kuzyk ZZA, Gari BD, Munishi L, Mtei K, Nebiyu A, Mabit L, Navas A, Semmens BX (2018) A deconvolutional Bayesian mixing model approach for river basin sediment source apportionment. Sci Rep 8:13073

Borrelli P, Robinson DA, Fleischer LR, Lugato E, Ballabio C, Alewell C, Meusburger K, Modugno S, Schütt B, Ferro V, Bagarello V (2017) An assessment of the global impact of 21st century land use change on soil erosion. Nat Commun 8(1):2013. https://doi.org/10.1038/ s41467-017-02142-7

Brooks SP, Gelman A (1997) General methods for monitoring convergence of iterative simulations. J Comput Graph Stat 7:434-455

Calvert AJ, Andrews GDM (2014) New geoscientific constraints on the hydrocarbon potential of the Nechako-Chilcotin plateau of central British Columbia. Can J Earth Sci 51:v-ix

Chen C-H, Hsieh T-Y, Yang J-C (2017) Investigating effect of water level variation and surface tension crack on riverbank stability. J HydroEnviron Res 15:41-53

Collins AL, Walling DE, Leeks GJL (1997) Use of the geochemical record preserved in floodplain deposits to reconstruct recent changes in river basin sediment sources. Geomorphology 19:151-167

Collins AL, Pulley S, Foster IDL, Gellis A, Porto P, Horowitz AJ (2017) Sediment source fingerprinting as an aid to catchment management: a review of the current state of knowledge and a methodological decision-tree for end users. J Environ Manag 194:86-108

Colman SM, Foster DS (1994) A sediment budget for southern Lake Michigan: source and sink models for different time intervals. J Great Lakes Res 20:215-228

Cook SJ, Dunn CE (2006) Final report on results of the Cordilleran geochemistry project: a comparative assessment of soil geochemical methods for detecting buried mineral deposits - 3Ts Au-Ag prospect, central British Columbia. Report 2007-7. Geoscience BC, Vancouver, $225 \mathrm{pp}$

Cooper RJ, Krueger T (2017) An extended Bayesian sediment fingerprinting mixing model for the full Bayes treatment of geochemical uncertainties. Hydrol Process 31:1900-1912

Danard M, Murty TS (1994) On recent climate trends in selected salmonhatching areas of British Columbia. J Clim 7:1803-1808

Davies J, Olley J, Hawker D, McBroom J (2018) Application of the Bayesian approach to sediment fingerprinting and source attribution. Hydrol Process 32:3978-3995

Davison W, Hilton J, Hamilton-Taylor J, Kelly M, Livens F, Rigg E, Carrick TR, Singleton DL (1993) The transport of Chernobylderived radiocaesium through two freshwater lakes in Cumbria, UK. J Environ Radioact 19:125-153

Déry SJ, Hernandez-Henriquez MA, Owens PN, Parkes MW, Petticrew EL (2012) A century of hydrological variability and trends in the Fraser River Basin. Environ Res Lett 7:024019. https://doi.org/10. 1088/1748-9326/7/2/024019

D'Haen K, Verstraeten G, Degryse P (2012) Fingerprinting historical fluvial sediment fluxes. Prog Phys Geogr 36:154-186

Dorcey AHJ, Griggs JR (1991) Water in sustainable development: exploring our common future in the Fraser River basin. University of British Columbia, Westwater Research Centre, Vancouver, $288 \mathrm{pp}$ 
French TD, Chambers PA (1997) Reducing flows in the Nechako River (British Columbia, Canada): potential response of the macrophyte community. Can J Fish Aquat Sci 54:2247-2254

Fu B, Newham LTH, Ramos-Scharrón CE (2010) A review of surface erosion and sediment delivery models for unsealed roads. Environ Model Softw 25:1-14

Gelman A, Rubin DB (1992) Inference from iterative simulation using multiple sequences. Stat Sci 7:457-511

Geweke J (1992) Evaluating the accuracy of sampling-based approaches to calculating posterior moments. In: Bernardo JM, Berger JO, Dawid AP, Smith AFM (eds) Bayesian statistics 4. Clarendon Press, Oxford, UK, pp 169-193

Hartman (1996) Impacts of growth in resource use and human population on the Nechako River: a major tributary of the Fraser River, British Columbia, Canada. Geosci J 40:147-164

Jaremoviec L, Rowland D (1988) Review of Chinook salmon escapements in the Nechako River, British Columbia. Can MS Rep Fish Aquat Sci 1963, Department of Fisheries and Oceans, Nanaimo, BC, $135 \mathrm{pp}$

Joshi SR (1986) Early observations on Chernobyl fallout in Canada. National Water Research Institute, Report En13-5/86-182E. Environment Canada, Burlington

Joshi SR (1988) The fallout of Chernobyl radioactivity in Central Ontario, Canada. J Environ Radioact 6:203-211

Julian JP, Torres R (2006) Hydraulic erosion of cohesive riverbanks. Geomorphol 76:193-206

Kang DH, Gao H, Shi X, Islam SU, Déry SJ (2016) Impacts of a rapidly declining mountain snowpack on streamflow timing in Canada's Fraser River basin. Sci Rep 6:19299

Kemp ALW, Dell CI, Harper NS (1978) Sedimentation rates and a sediment budget for Lake Superior. J Great Lakes Res 4:276-287

Koiter AJ, Lobb DA, Owens PN, Petticrew EL, Tiessen KHD, Li S (2013a) Investigating the role of connectivity and scale in assessing the sources of sediment in an agricultural watershed in the Canadian prairies using sediment source fingerprinting. J Soils Sediments 13: 1676-1691

Koiter AJ, Owens PN, Petticrew EL, Lobb DA (2013b) The behavioural characteristics of sediment properties and their implications for sediment fingerprinting as an approach for identifying sediment sources in river basins. Earth-Sci Rev 125:24-42

Koiter AJ, Owens PN, Petticrew EL, Lobb DA (2018) Assessment of particle size and organic matter correction factors in sediment source fingerprinting investigations: the example of two contrasting watersheds in Canada. Geoderma 325:195-207

Laceby JP, Evrard O, Smith HG, Blake WH, Olley JM, Minella JPG, Owens PN (2017) The challenges and opportunities of addressing particle size effects in sediment source fingerprinting: a review. Earth-Sci Rev 169:85-103

Liu K, Lobb DA, Miller JJ, Owens PN, Caron MEG (2018) Determining sources of fine-grained sediment for a reach of the Lower Little Bow River, Alberta, using a colour-based sediment fingerprinting approach. Can J Soil Sci 98:55-69

Mabit L, Benmansour M, Abril JM, Walling DE, Meusburger K, Iurian $\mathrm{AR}$, Bernard $\mathrm{C}$, Tarjan $\mathrm{S}$, Owens $\mathrm{PN}$, Blake WH, Alewell C (2014) Fallout lead-210 as a soil and sediment tracer in catchment sediment budget investigations: a review. Earth-Sci Rev 138:335-351

McAdam SO, Walters CJ, Nistor C (2005) Linkages between white sturgeon recruitment and altered bed substrates in the Nechako River, Canada. Trans Am Fish Soc 134:1448-1456

Morgan RPC (2005) Soil erosion and conservation, 3rd edn. Wiley, Blackwell, $304 \mathrm{pp}$

Nearing MA, Jetten V, Baffaut C, Cerdan O, Couturier A, Hernandez M, Le Bissonnais Y, Nichols MH, Nunes JP, Renschler CS, Souchère V, Van Oost K (2005) Modeling response of soil erosion and runoff to changes in precipitation and cover. Catena 61:131-154
Nener JC, Wernick BG (2000) Fraser River basin strategic water quality plan, middle and north Fraser sub-basins. Fisheries and Oceans Canada (Fraser River Action Plan), Habitat and Enhancement Branch, Vancouver, $207 \mathrm{pp}$

NRC (2018) Mountain pine beetle: the threat of mountain pine beetle to Canada's boreal forest. Natural Resources Canada. https://www. nrcan.gc.ca/forests/fire-insects-disturbances/top-insects/13381. Accessed 11 Feb 2019

Owens PN, Walling DE (2002) Changes in sediment sources and floodplain deposition rates in the catchment of the River Tweed, Scotland, over the last 100 years: the impact of climate and land use change. Earth Surf Process Landf 27:403-423

Owens PN, Walling DE, Leeks GJL (1999) Use of floodplain sediment cores to investigate recent historical changes in overbank sedimentation rates and sediment sources in the catchment of the River Ouse, Yorkshire, UK. Catena 36:21-47

Owens PN, Blake WH, Gasper L, Gateuille D, Koiter AJ, Lobb DA, Petticrew EL, Reiffarth DG, Smith HG, Woodward JC (2016) Fingerprinting and tracing the sources of soils and sediments: earth and oceans science, geoarchaeological, forensic, and human health applications. Earth-Sci Rev 162:1-23

Owens PN, Gateuille DJ, Petticrew EL, Booth BP, French TD (2019) Sediment-associated organopollutants, metals and nutrients in the Nechako River, British Columbia: a current study with a synthesis of historical data. Can Water Resour J 44:42-64. https://doi.org/10. 1080/07011784.2018.1531063

Parnell AC, Phillips DL, Bearhop S, Semmens BX, Ward EJ, Moore JW, Jackson AL, Grey J, Kelly DJ, Inger R (2013) Bayesian stable isotope mixing models. Environmetrics 24:387-399

Phillips JM, Russell MA, Walling DE (2000) Time-integrated sampling of fluvial suspended sediment: a simple methodology for small catchments. Hydrol Process 14:2589-2602

Picketts IM, Parkes MW, Déry SJ (2017) Climate change and resource development impacts in watersheds: insights from the Nechako River Basin, Canada. Can Geogr 61:196-211

Plummer M (2003) JAGS: a program for analysis of Bayesian graphical models using Gibbs sampling, Proceedings of the 3rd International Workshop on Distributed Statistical Computing, Vienna, Austria

R Core Team (2016) R: a language and environment for statistical computing. R Foundation for Statistical Computing, Vienna, Austria. https://www.R-project.org/. Accessed 11 April 2018

Reiffarth DG, Petticrew EL, Owens PN, Lobb DA (2016) Sources of variability in fatty acid (FA) biomarkers in the application of compound-specific stable isotopes (CSSIs) to soil and sediment fingerprinting and tracing: a review. Sci Total Environ 565:8-27

Schindler DW, Smol JP (2006) Cumulative effects of climate warming and other human activities on freshwaters of Arctic and subarctic North America. Ambio 35:160-168

Smith HG, Blake WH (2014) Sediment fingerprinting in agricultural catchments: a critical re-evaluation of source discrimination and data corrections. Geomorphol 204:177-191

Smith TA, Owens PN (2014a) Individual and cumulative effects of agriculture, forestry and metal mining activities on the metal and phosphorus content of fine-grained sediment; Quesnel River basin, British Columbia, Canada. Sci Total Environ 496:435-442

Smith TB, Owens PN (2014b) Flume- and field-based evaluation of a time-integrated suspended sediment sampler for the analysis of sediment properties. Earth Surf Process Landf 39:1197-1207

Smith ML, Taylor HW, Sharma HD (1993) Comparison of the postChernobyl ${ }^{137} \mathrm{Cs}$ contamination of mushrooms from eastern Europe, Sweden, and North America. Appl Environ Microbiol 59: 134-139

Stock BC, Semmens BX (2016a) MixSIAR GUI user manual. Version 3.1. https://github.com/brianstock/MixSIAR. Accessed March 2018 
Stock BC, Semmens BX (2016b) Unifying error structures in commonly used biotracer mixing models. Ecology 97:2562-2569

Vörösmarty CJ, McIntyre PB, Gessner MO, Dudgeon D, Prusevich A, Green P, Glidden S, Bunn SE, Sullivan CA, Reidy Liermann C, Davies PM (2010) Global threats to human water security and river biodiversity. Nature 467:555-561

Walling DE (2013) The evolution of sediment source fingerprinting investigations in fluvial systems. J Soils Sediments 13:1658-1675

Walling DE, Owens PN, Foster IDL, Lees JA (2003) Changes in fine sediment dynamics of the Ouse and Tweed basins in the UK, over the last 100-150 years. Hydrol Process 17:3245-3269
Ward EJ, Semmens BX, Schindler DE (2010) Including source uncertainty and prior information in the analysis of stable isotope mixing models. Environ Sci Technol 44:4645-4650

Wohl E, Brierley G, Cadol D, Coulthard TJ, Covino T, Fryirs KA, Grant G, Hilton RG, Lane SN, Magilligan FJ, Meitzen KM, Passalacqua P, Poepple RE, Rathburn SL, Sklar LS (2019) Connectivity as an emergent property in geomorphic systems. Earth Surf Process Landf 44:4-26

Publisher's note Springer Nature remains neutral with regard to jurisdictional claims in published maps and institutional affiliations. 